RESEARCH ARTICLE / Araştırma Makalesi

DOI: 10.5505/sakaryamedj.2016.37232

\title{
Prevalance of Non-Coronary Findings in Patients Undergoing Cardiac Multidetector Computed Tomography Scans
} - Kardiyak Çok Kesitli Bilgisayarlı Tomografi ille Değerlendirìlen Has̊talarda Koroner Dişı Bullguların Prevalansi

\section{Fatih Kılınç ${ }^{1}$, Ahmet Göktuğ Ertem², Tağmaç Deren³ ${ }^{3}$ Lale Paşaoğlu ${ }^{3}$, Gökçen Yükünç ${ }^{4}$, Salih Süha Koparal ${ }^{3}$}

- $\quad{ }^{1}$ Ankara Ceza Infaz Kurumları Kampüs Devlet Hastanesi, Radyoloji Kliniği, Ankara

${ }^{2}$ Ankara Ceza İnfaz Kurumları Kampüs Devlet Hastanesi, Kardiyoloji Kliniği, Ankara

${ }^{3}$ Ankara Numune Eğitim ve Araştırma Hastanesi, Radyoloji Kliniği, Ankara

${ }^{4}$ Of Devlet Hastanesi, Radyoloji Kliniği, Trabzon

\section{Abstract}

Aim To investigate non-coronary findings during coronary calcium scoring with computed tomography.

Material 190 patients who were evaluated with multislice computed tomography for coronary calcium scoring, were included in the study. Nonand Method coronary findings were described as Minor and Major A-B findings.

Results One hundred seventy seven non-coronary findings were found at $80(42.1 \%)$ patients. There were minor findings at $40(21 \%)$ and major findings at $40(21 \%)$ of the patients. There were 13 Major B findings including aortic aneurysm, pulmonary mass, pulmonary nodules, infiltrates, pneumonectomy, surrenal nodular thickening and liver mass lesions.

Conclusion Non-coronary findings are frequent, and radiologist and/or cardiologist who has been reporting these findings should be aware of the frequency and importance of these findings. ( Sakarya Med J 2016, 6(4):224-230 )

Keywords Coronary calcium score; Multislice computed tomography; Non-coronary findings

Amaç çok kesitli bilgisayarı tomografi ile yapılan koroner kalsiyum skorlaması sırasında kalp dışı bulguları incelemek.

Materyal Çalışmaya 190 çok kesitli bilgisayarlı tomografi ile koroner kalsiyum skorlaması yapılan hasta alındı. Kalp dışı bulgular Minor, Major ve Metod A-B olarak tanımlandı.

Bulgular Çalışmaya alınan hastalardan 80'inde 177 kalp dışı bulgu tespit edildi (42.1\%). Bu hastaların 40'ında minor bulgular (21\%), 40'ında major bulgular (21\%) mevcuttu. Majör B bulgular aort anevrizması, akciğerde kitle, akciğer nodülleri ve infiltrasyonları, pnömonektomi, böbrek üstü bezde nodüler kalınlașma ve karaciğer kitle lezyonlarını içermektedir.

Sonuç Kalp dışı bulgular sık görülür. Bu bulguları raporlayan radyolog ve/veya kardiyologlar, bu bulguların sıklığı ve önemi konusunda dikkatli olmalıdırlar. ( Sakarya Tıp Dergisi 2016, 6(4):224-230).

Anahtar Kelimeler Koroner kalsiyum skoru, koroner dışı bulgular, çok kesitli bilgisayarlı tomografi 


\section{INTRODUCTION}

In developed countries, cardiovascular disease (CVD) is the leading cause of death, and will be the most important cause of mortality and morbidity in developed countries by $2020^{1}$. Coronary artery disease (CAD) is the most common clinical result that develops in presence of atherosclerosis during CVD. Because of this condition, the screening tests (multislice computed tomography (MSCT), etc.) for this disease are crucial².

Electron Beam Computed Tomography (EBCT) and MSCT are used for non-invasive cardiac imaging, and coronary artery calcium scoring (CACS). Coronary calcium scoring with MSCT is a commonly used, noninvasive imaging method that has been regarded as gold standard for the determination of calcification on coronary arteries ${ }^{3}$. The heart, the great vessels, and coronary arteries, as well as lungs, bones, and the upper abdomen can be screened and evaluated with MSCT.

The aim of this study was to determine the incidence of noncoronary findings (NCF) during CACS with MSCT, and to search for whether there is a relationship between CAD risk factors and non-coronary findings with CACS.

\section{MATERIALS and METHODS}

One hundred ninety patients who were evaluated with 16-detector MSCT (Toshiba multislice Aquilion 16 system, Toshiba Medical Systems, Otawara, Japan) for CACS, were included in the study. History of hypertension (HT), diabetes mellitus (DM), smoking, hyperlipidemia (HL), myocardial infarction (MI), percutaneous coronary intervention, coronary artery bypass operation, and heart failure were recorded for each individual. The images at CT work station (Vitrea, Toshiba) were observed by two radiologists and one cardiologist who were blinded to individuals. This retrospective study was approved by our local ethics committee.

According to Agatston scoring which is a method based on coronary calcium scoring, for 2-3 pixels adjacent to each other in an area wider than $1 \mathrm{~mm} 2$, lesions whose CT densities has been higher than 130 Hounsfield unit (HU), are significant for calcification ${ }^{5,6}$. All non-coronary findings were noted. Noncoronary findings were divided into major and minor. Major group was also divided into two subgroups, major A and ma- jor B. Minor group described as insignificant clinical findings, major A group described as moderately severe findings that require follow-up, major B group described as findings that are remarkable, need to search etiology, and require further examination and/or treatment.

Calcified nodules in lung, fibrotic band, bullous emphysema, atelectasis, bronchiectasis, calcified mediastinal lymph nodes smaller than $1 \mathrm{~cm}$, pleural calcifications, and calcifications of atherosclerotic plaque in the aorta intense, widespread degeneration of vertebrae, hemangioma, spondylosis, liver cyst, steatosis, calcification, hiatal hernia, bochdalek hernia and splenic calcification were included in minor findings. Larger than $5 \mathrm{~mm}$ noncalcificated nodules, areas of frosted glass density, cavitation, mediastinal lymph nodes larger than $1 \mathrm{~cm}$, pleural thickening, valve calcifications, pericardial calcification, and effusion, the ascending aorta with diameter of 40$50 \mathrm{~mm}$, increase in pulmonary artery diameter, pneumobilia, and ascites were included in major A group.

Amongst the nodules in lung whose diameters were larger than $10 \mathrm{~mm}$, smooth-edged nodules were also included in this group. $13 \mathrm{~mm}$ nodule which has suspected irregularity of contour that was seen in lung, two unidentified hypodense lesion in the liver, nodular thickening at surrenal gland, infiltration at lung, pulmonary solid mass, pneumonectomy, and aortic aneurysm with diameter of $>50 \mathrm{~mm}$ were included in major B group.

\section{Statistical analysis}

All statistical analysis were done by SPSS 15.0 (SPSS for Windows; SPSS Inc., Chicago, IL, USA). For discrete and continuous data, percentage and median (min-max) values were used in descriptive statistics, respectively. For comparison between groups with discrete variables and continuous variables, the chi-square and Mann-Whitney $U$ tests were used, respectively. To determine independent risk factors, logistic regression analysis was done. A p value $<0.05$ were accepted as significant.

\section{RESULTS}

Clinical and demographical findings of NCF (+) and NCF (-) groups are shown in Table 1. Of 190 patients 107 was male 
(56.3\%) and 83 was female (43.7\%) included in our study. The mean age was $53.95 \pm 14.05$ years. Agatston score 0 was at 101 cases (53\%), and Agatston score $>400$ was found at 16 cases (8.4\%) (Figure 1). In our study, a total of 177 noncoronary findings were observed at 80 cases $(42 \%) .52$ of the NCF were found in lungs [Minor findings were calsific nodule $<1 \mathrm{~cm}, 5$ (2.6\%); fibrotic band, 14 (7.3\%); emphysema, bulla, $8(4.2 \%)$; atelectasia, 5 (2.6\%), bronchiectasia, $2(1 \%)$; major A findings were calsific nodule $<1 \mathrm{~cm}, 5(2.6 \%)$; fibrotic band, $14(7.3 \%)$; noncalsific nodule < $8 \mathrm{~mm}, 9(4.7 \%)$; infiltration, $2(1 \%)$; cavitation, $1(0.5 \%)$; major B findings were nodule $>8 \mathrm{~mm}, 1$ (0.5\%); infiltration, 2 (1\%); solid mass, 1 (0.5\%); pneumonectomy, $1(0.5 \%)]$,

Table 1. Clinical and demographical characteristics of non-coronary findings $(+)$ and $(-)$ patients

\begin{tabular}{|c|c|c|c|}
\hline & $\begin{array}{l}\text { NCF (-) n } \\
(\%)\end{array}$ & $\begin{array}{l}\text { NCF (+) n } \\
(\%)\end{array}$ & $\begin{array}{c}\text { Total } n \\
(\%)\end{array}$ \\
\hline Number of patients (n) & 110 & 80 & 190 \\
\hline Average age & 51.74 & 57.00 & 53.95 \\
\hline$<40$ years & $24(21.8)$ & $14(17.5)$ & $38(20.0)$ \\
\hline $40-59$ years & $54(49.1)$ & $26(32.5)$ & $80(42.1)$ \\
\hline$\geq 60$ years & $32(29.1)$ & $40(50.0)$ & 72 (37.9) \\
\hline Male & $64(58.2)$ & $43(53.8)$ & $107(56.3)$ \\
\hline History of coronary angiography & $18(16.4)$ & $7(8.8)$ & $25(13.2)$ \\
\hline $\begin{array}{l}\text { History of coronary bypass } \\
\text { surgery }\end{array}$ & $0(\% 0)$ & $1(1.2)$ & $1(0.5)$ \\
\hline Hypertension & $49(44.5)$ & $37(46.2)$ & $86(45.3)$ \\
\hline Diabete mellitus & $20(18.2)$ & $26(32.5)$ & $46(24.2)$ \\
\hline Smoking & $48(43.6)$ & $51(63.8)$ & $99(52.1)$ \\
\hline Hyperlipidemia & $52(47.3)$ & $54(67.5)$ & $106(55.8)$ \\
\hline Chest pain & $61(55.5)$ & $34(42.5)$ & $95(50.0)$ \\
\hline Dispnea & $28(25.5)$ & $23(28.8)$ & $51(26.8)$ \\
\hline Prior myocardial infarction & $9(8.2)$ & $0(0)$ & $9(4.7)$ \\
\hline Heart failure & $3(2.7)$ & $2(2.5)$ & $5(2.6)$ \\
\hline \multicolumn{4}{|l|}{ Agatston score } \\
\hline 0 & $63(57.3)$ & $38(47.5)$ & $101(53.2)$ \\
\hline $1-10$ & $10(9.1)$ & $8(10.0)$ & $18(9.5)$ \\
\hline $11-100$ & $14(12.7)$ & $13(16.2)$ & $27(14.2)$ \\
\hline $101-400$ & $15(13.6)$ & $13(16.2)$ & $28(14.7)$ \\
\hline$>400$ & $8(7.3)$ & $8(10.0)$ & $16(8.4)$ \\
\hline \multicolumn{4}{|l|}{ NCF: non-coronary findings } \\
\hline
\end{tabular}

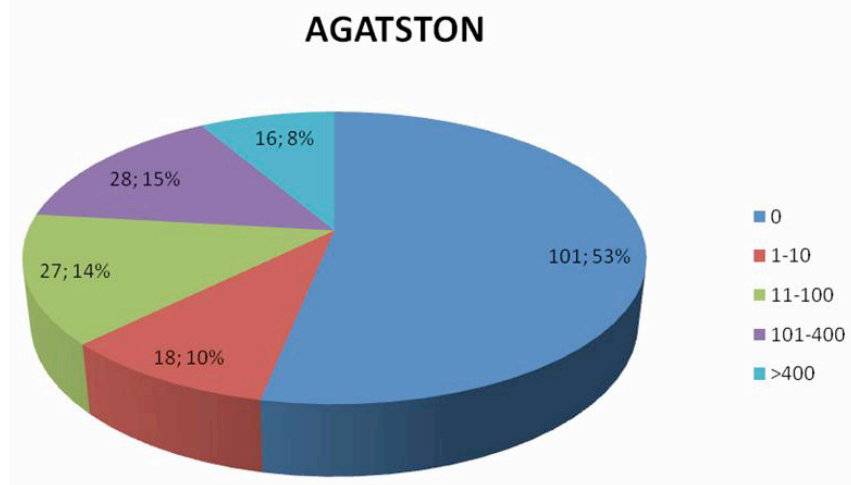

Figure 1. Distribution of the Agatston scores of the cases.

Twenty three of them were found in mediastinum, 10 of them were found in pleura, 36 of them were found at the cardiovascular system, 25 of them were found in vertebral and 31 of them found in abdomen (Figure 2). In NCF (+) group, age, smoking, $\mathrm{HL}$ and DM were higher than NCF (-) group. A total of 127 minor findings, 37 major $A$ findings, 13 major $B$ noncoronary findings in NCF (+) patients.

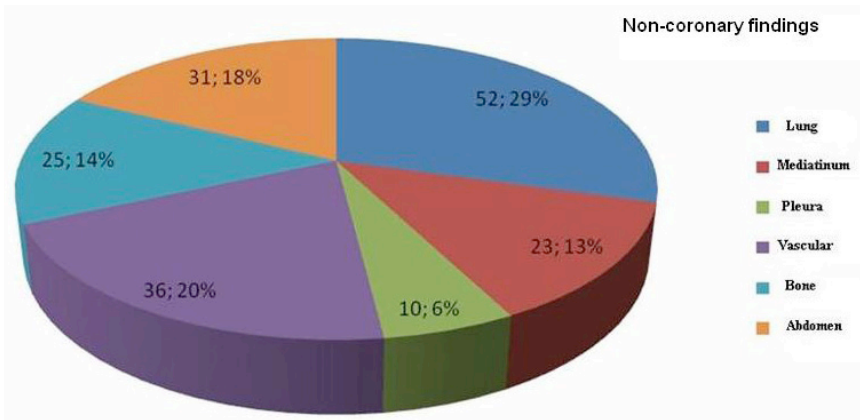

Figure 2. The distribution of the number of non-coronary findings by anatomic site.

Patients who were $>60$ years have significantly higher NCF than patients who were $<60$ years $(56 \%$, 34\%, respectively, $\mathrm{p}<0.05)$. Major A NCF $(22 \%$ - 10\%) and major B NCF were significantly higher in patients who were $>60$ years than patients who were in young and middle age groups $(p<0.05)$ (Table 2, Figure 3).

Comparison of two groups of which Agatston score was 0-400 and $>400$, is shown in Table 3. NCF was higher in Agatston score $>400$ patients than Agatston score $<400$ (n: 50, n: 42, respectively). In the group at which CACS was found higher than 400, the rate of Major B patients was found higher than the group at which Agatston score was 400 and below (13\%, 
Table 2. Relation between Agatston score, subgroup characteristic (gender and age) and non-coronary findings

\begin{tabular}{|c|c|c|c|c|c|c|c|c|c|}
\hline & $\mathrm{n}(\%)$ & $\begin{array}{c}\text { NCF }(+) \\
\mathrm{n}(\%)\end{array}$ & $\begin{array}{c}\text { Major A } \\
\text { group n (\%) }\end{array}$ & $\begin{array}{c}\text { Major B } \\
\text { group n (\%) }\end{array}$ & $\begin{array}{c}\text { Number of } \\
\text { NCF }\end{array}$ & $\begin{array}{c}\text { Major A NCF } \\
\mathrm{n}(\%)\end{array}$ & $\begin{array}{c}\text { Major B NCF } \\
\mathrm{n}(\%)\end{array}$ & $\begin{array}{c}\text { NCF I NCF (+) } \\
\text { patient ratio }\end{array}$ \\
\hline Agatston score \\
\hline$\leq 400$ & $174(92)$ & $72(42)$ & $25(14)$ & $11(6)$ & 164 & $34(21)$ & $11(7)$ & 2.3 \\
\hline$>400$ & $16(8)$ & $8(50)$ & $2(13)$ & $2(13)$ & 13 & $3(23)$ & $2(15)$ & 1.6 \\
\hline$<40$ years & $38(20)$ & $13(34)$ & $4(11)$ & $1(3)$ & 21 & $4(19)$ & $1(5)$ & 1.5 \\
\hline $40-59$ years & $80(42)$ & $27(34)$ & $7(9)$ & $4(5)$ & 48 & $8(17)$ & $4(8)$ & 1.8 \\
\hline$>60$ years & $72(38)$ & $40(56)$ & $16(22)$ & $8(11)$ & 108 & $25(23)$ & $8(7)$ & 2.7 \\
\hline Male & $107(56)$ & $43(40)$ & $11(10)$ & $9(8)$ & 97 & $19(21)$ & $9(9)$ & 2.3 \\
\hline Female & $83(44)$ & $37(45)$ & $16(22)$ & $4(5)$ & 80 & $18(25)$ & $4(5)$ & 2.2 \\
\hline
\end{tabular}

Table 3. Multivariate analysis of relationship between variables and non-coronary findings

\begin{tabular}{|c|c|c|c|c|}
\hline Variable & \multicolumn{4}{|c|}{ Odds ratio (\%95 Cl) } \\
\hline & NCF & Minor & Major A & Major B \\
\hline Age $\geq 60$ & $2.8(1.4-5.8)$ & $1.9(0.8-4.6)$ & $4.5(1.5-12.6)$ & $0.6(1.3-21.2)$ \\
\hline Female & $1.2(0.7-2.1)$ & $0.9(0.4-1.9)$ & $2.3(0.9-5.3)$ & $1.6(0.5-5.6)$ \\
\hline Male & $0.8(0.5-1.5)$ & $1.1(0.5-2.3)$ & $0.4(0.2-1.0)$ & $0.5(0.1-3.3)$ \\
\hline DM & $2.5(1.1-5.8)$ & $3.2(1.2-8.5)$ & $3.4(1.1-10.7)$ & $3.1(0.7-14.9)$ \\
\hline Smoking & $2.1(1.1-4.1)$ & $2.0(0.8-4.8)$ & $3.1(1.1-8.9)$ & $1.1(0.2-6.9)$ \\
\hline Agatston score $\geq 400$ & $0.6(0.2-2.0)$ & $0.7(0.2-2.9)$ & $0.4(0.1-2.3)$ & $3.3(0.8-13.1)$ \\
\hline HL & $2.0(1.0-3.9)$ & $1.9(0.8-4.2)$ & $1.8(0.7-4.7)$ & $1.4(0.3-5.4)$ \\
\hline Chest pain & $0.4(0.2-0.8)$ & $0.4(0.2-0.8)$ & $0.3(0.1-0.8)$ & $0.6(0.2-2.6)$ \\
\hline HT & $0.5(0.3-1.1)$ & $0.6(0.2-1.4)$ & $0.4(0.1-1.3)$ & \\
\hline Cl: Confidence Interval, NCF: non-coronary findings, DM: Diabetes mellitus, HL: Hyperlipidemia, HT: Hypertension &
\end{tabular}

$6 \%$, respectively). Major B NCF were higher but not significant in Agatston score >400 than Agatston score <400 (15\%, 7\%, respectively, p>0.05) (Table 2 ).

Among the significant abnormalities, the three most common were pulmonary nodules (16.7\%), emphysema (16.7\%) and possible hepatic carcinomas (12.6\%).

The multivariate analysis on the potential relationship between $C A D$ risk factors and non-coronary findings is shown on Table 3. The significant positive relationship between age, smoking, DM, HL and all NCF was found.

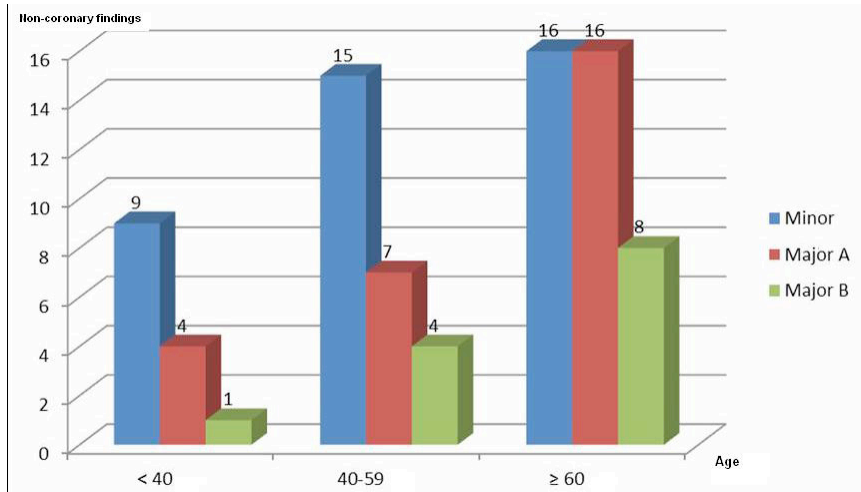

Figure 3.. Number of cases with non-coronary findings found in minor, major groups $A$ and $B$ according to age groups. 
Table 4. Incidental non-coronary findings in cardiac imaging: Literature summary

\begin{tabular}{|c|c|c|c|c|c|c|}
\hline Authors & Year & Study & Type of CT & Number of patient & Minor ECF & Major ECF \\
\hline Hunold et al. ${ }^{6}$ & 2001 & CACS & $\mathrm{EBCT}$ & 1812 & $53 \%$ & $11 \%$ \\
\hline Onuma et al. ${ }^{7}$ & 2006 & Coronary MSCT & $16+64 \mathrm{MSCT}$ & 503 & $58.1 \%$ & $22.7 \%$ \\
\hline Greenberg-Wolff et al. ${ }^{8}$ & 2008 & Coronary MSCT & $40 \mathrm{MSCT}$ & 134 & $76.8 \%$ & $39 \%$ \\
\hline Chia et al. ${ }^{9}$ & 2009 & Coronary MSCT & $64 \mathrm{MSCT}$ & 1061 & $8.0 \%$ & $3.1 \%$ \\
\hline Koonce et al. ${ }^{10}$ & 2009 & Coronary MSCT & $64 \mathrm{MSCT}$ & 737 & $26.6 \%$ & $20.2 \%$ \\
\hline Dewey et al. ${ }^{11}$ & 2007 & Coronary MSCT & $16 \mathrm{MSCT}$ & 108 & $10 \%$ & $5 \%$ \\
\hline Kawano et al. ${ }^{12}$ & 2007 & Coronary MSCT & $64 \mathrm{MSCT}$ & 625 & $24.1 \%$ & $5.8 \%$ \\
\hline Horton et al. ${ }^{14}$ & 2002 & CACS & EBCT & 1326 & $7.8 \%$ & $5 \%$ \\
\hline Haller et al. ${ }^{15}$ & 2006 & Coronary MSCT & $16 \mathrm{MSCT}$ & 166 & $19.9 \%$ & $4.8 \%$ \\
\hline Türkvatan et al. ${ }^{16}$ & 2009 & Coronary MSCT & $16 \mathrm{MSCT}$ & 375 & $22.1 \%$ & $19.2 \%$ \\
\hline Bendix et al. ${ }^{19}$ & 2011 & Coronary MSCT & $128 \mathrm{MSCT}$ & 1383 & $22 \%$ & $6.8 \%$ \\
\hline
\end{tabular}

ECF: non-coronary findings, MDCT: multidetector computerized tomography, EBCT: electron beam computerized tomography, CACS: coronary calcium score

\section{DISCUSSION}

The presence of calcification in coronary arteries is sign of the coronary atherosclerosis. Studies have shown that there is a linear relationship between the amount of calcium and the total atherosclerotic plaque burden. In advanced ages, the amount and distribution of coronary artery calcium provides valuable information to predict the risk of $\left(\mathrm{CV}^{4}\right)$. EBCT and MSCT are non-invasive diagnostic methods that determine the presence and amount of coronary artery calcium in both asymptomatic and symptomatic patients. To search noncoronary findings during calcium scoring by MSCT is crucial because of the factors such as explaining clinical symptoms of the patient, detecting the presence of an underlying malignancy or providing early diagnosis and treatment.

At previous studies done with EBCT and MSCT, incidental NCF ratio was $8-77 \%$. (Table 4). Most of these findings (atelectasis, hepatic cyst, etc.) were unremarkable ${ }^{5-14}$. In previous studies clinically significant NCF (pneumonia, malignancy, aneurysms, etc.) rates were between 3-39\% $\%^{9,10}$. Moreover, the presence of heterogenity in NCF ratios may depend on the differences between the definitions of NCF and MSCT upprotocol.

Greenberg-Wolff et al. found that one or more NCF in $76.8 \%$ of the patients, and remarkable NCF ratio is $39 \%$, but in our study this ratio was found less ${ }^{8}$. Turkvatan et al. found that
$22.1 \%$ of the 375 patients have unimportant non-coronary findings, and at $19.2 \%$ of them has important non-coronary findings ${ }^{15}$. These ratios are similar with our study. At MSCT for calcium scoring or coronary angiography, incidental pulmonary nodule incidence changed between $5 \%$ to $20 \%, 6,7,12,13,15$ 17. In our study, there were found non-calcificated nodule in totally 11 patients. 10 of them were included in Major $A$, and one of them was included in major $B$ group because of its suspicious image.

In our study, there was positive correlation between age and incidental findings, like previous studies ${ }^{6,9,18}$. There are few studies which investigate the correlation between CACS and presence of NCF, risk factors, symptoms in literature ${ }^{19}$. Similarly in our study, the strongest correlation with presence of NCF was age.

Different from previous study, in our study there were significant correlations between $\mathrm{HL}, \mathrm{DM}$ and presence of $\mathrm{NCF}^{19}$. Bendix et al. could not demonstrate significant correlation between Agatston scoring, gender and presence of NCF, we also could not found these relations in our study ${ }^{19}$. Budoff and his colleagues argued that an extra study for searching noncardiac findings, analyzing the data of MSCT again may cause unnecessary anxiety in patients, extra costs and radiation dose and moreover, it may cause potential risks related to invasive diagnostic tests, in turn, these studies did not have any pro- 
ven benefit ${ }^{20}$. Similarly, Machaalany and colleagues postulated that to analyze the NCF has no clear benefit on mortality but it would lead to additional costs and morbidity seriously ${ }^{18}$. When the detected findings in our study such as aortic aneurysm, pulmonary mass, liver mass, pulmonary nodule were taken into account, we thought that CACS examination with MSCT should be evaluated by cardiac imaging specialist, and using different image field settings and not just concentrate on the heart but all extracardiac fields when detected.

\section{CONCLUSION}

In patients on whom CACS is applied by MSCT, incidental noncoronary findings were seen frequently, and sometimes clinically important findings such as malignancy, aneurysm can be found. Age, smoking, diabetes and $\mathrm{HL}$ have a relationship with the presence of non-coronary findings. The follow-up of major non-coronary findings or the research for diagnosis and treatment in case of clinical necessity are important for early diagnosis and treatment.

Conflict of interest: None declared. 
1. Mathers CD, Lopez AD, Murray CJL. The Burden of Disease and Mortality by Condition: Data, Methods, and Results for 2001. In: Lopez AD, Mathers CD, Ezzati M, Jamison DT, Murray CJL, editors. Global Burden of Disease and Risk Factors. Washington (DC): World Bank; 2006. Chapter 3..

2. Umman, S. Coronary artery calcium scoring method. Anadolu Kardiyol Derg. 2008; 8: 12 -14.

3. Erdogan $\mathrm{N}$, Altin L, Altunkan S. Elektron beam tomografi ile koroner arterlerdeki kalsiyum miktarinin saptanmasi. Diagn Interv Radiol. 2002; 8(4): 533-537.

4. Schmermund $A$, Mohlenkamp $S$, Erbel R. The latest on the calcium story. Am J Cardiol. 2002; 90(10C): 12L-14L.

5. Janowitz WR, Agatston AS, Kaplan G, Viamonte M Jr. Differences in prevalence and extent of coronary artery calcium detected by ultrafast computed tomography in asymptomatic men and women. Am J Cardiol. 1993; 72(3): 247-254.

6. Hunold P, Schmermund A, Seibel RM, Grönemeyer DH, Erbel R. Prevalence and clinical significance of accidental findings in electronbeam tomographic scans for coronary artery calcification. Eur Heart J. 2001; 22(18): 1748-1758.

7. Onuma $Y$, Tanabe $K$, Nakazawa $G$, Aoki J, Nakajima $H$, Ibukuro $K$, et al. Noncardiac findings in cardiac imaging with multidetector computed tomography. J Am Coll Cardiol. 2006; 48(2): 402 -406.

8. Greenberg-Wolff I, Uliel L, Goitein O, Shemesh J, Rozenman J, Di Segni E, et al. Extra-cardiac findings on coronary computed tomography scanning. Isr Med assoc J. 2008; 10: 806-808.

9. Chia PL, Kaw G, Wansaicheong G, Ho KT. Prevalence of non-cardiac findings in a large series of patients undergoing cardiac multi -detector computed tomography scans. Int J Cardiovas Imag. 2009; 25: 537-543.

10. Koonce J, Schoepf JU, Nguyen SA, Northan MC, Ravenel JG. Extra-cardiac findings at cardiac CT: experience with 1764 patients. Eur Radiol. 2009; 19: 570-576.

11. Dewey M, Schnapauff D, Teige F, Hamm B. Non-cardiac findings on coronary computed tomography and magnetic resonance imaging. Eur Radiol. 2007; 17: 2038 -2043.

12. Kawano Y, Tamura A, Goto Y, Shinozaki K, Zaizen H, Kadota J. Incidental detection of cancers and other non -cardiac abnormalities on coronary multislice computed tomography. Am J Cardiol. 2007; 99: 1608- 1609.

13. Haller S, Kaiser C, Buser P, Bongartz G, Bremerich J. Coronary artery imaging with contrast -enhanced MDCT: non-coronary findings. Am J Roentgenol. 2006; 187: 105-110.

14. Horton KM, Post WS, Blumenthal RS, Fishman EK. Prevalence of significant noncardiac findings on electronbeam computed tomography coronary artery calcium screening examinations. Circulation. 2002;106(5):532-4.

15. Gil BN, Ran K, Tamar G, Shmuell F, Eki A. Prevalence of significant noncardiac findings on coronary multidetector computed tomography angiography in asymptomatic patients. J Comput Assist Tomo. 2007; 31(1): 1-4.

16. Turkvatan A, Ozdemir Akdur P, et al. Prevelance of incidental non-coronary findings on multidetector computed tomographic coronary angiography. Turk Klin Tip Bilim. 2009; 29(1): 169-175

17. Schragin JG, Weissfeld JL, Edmundowicz D, Strollo DC, Fuhrman CR. Non -cardiac findings on coronary electron beam computed tomography scanning. J Thorac Imag. 2004; 19(2): $82-86$

18. Machaalany J, Yam Y, Ruddy TD, Abraham A, Chen $L$, Beanlands RS, et al. Potential clinical and economic consequences of noncardiac incidental findings on cardiac computed tomography . J Am Coll Cardiol. 2009; 54 1533-1541.

19. Bendix K, Jensen JM, Poulsen S, Mygind N, Norgaard BL. Coronary dual source multi detector computed tomography in patients suspected of coronary artery disease: Prevalence of incidental non - coronary findings. Eur J Radiol. 2011; 80: 109-114

20. Budoff MJ, Fischer H, Gopal A. Incidental findings with cardiac CT evaluation: should we read beyond the heart? Catheter Cardio Inte. 2006: 68: 965-973. 